The Rockefeller University has made 11 grants-in-aid to support projects requiring substantial research in the holdings of the Rockefeller Archive Center during 1979. The grant recipients were Pnina G. Abir-Am, Stanley Cobun, Donald Fisher, Lawrence C. Kelly, John Klein, Alfred A. Moss, Jr., Ronald F. Movrich, Robert Wayne Seidel, John Alexander Williams, Ka-che Yip, and Joan Grace Zimmerman.

Grants ranging from $\$ 500$ to $\$ 1000$ will be made to graduate students or advanced scholars engaged in similar projects for the year 1980. Applications for grants during 1980 should be made before December 31, 1979. The names of recipients will be announced on or before March 31, 1980.

Inquiries about the program and the open collections at the Center should be addressed to: Director, Rockefeller Archive Center, Hillcrest, Pocantico Hills, North Tarrytown, New York 10591.

\title{
ANNOUNCEMENT II
}

The Berkshire Conference of Women Historians will award its annual prizes for the best book and the best article in any field of history written by a woman and published during 1979. Submissions for the book should be sent to Professor Carol S. Gruber, Department of History, William Paterson College of New Jersey, Wayne, New Jersey, 07470 and for the article award to Professor Doris Goldstein, Department of History, Yeshiva University, 245 Lexington Avenue, New York, N.Y. 10016. Two copies of the book or article are required. Deadline for submission is February 1, 1980.

\section{ANNOUNCEMENT III}

The 1980 meetings of the Social Science History Association will be held in the Fall in Rochester, New York, hosted by the State University of New York at Brockport. Any interested in proposing a paper or preferably a panel should contact:

\author{
Harvey J. Graff \\ The Newberry Library \\ 60 West Walton Street \\ Chicago, Ill. 60610
}


The Children's Literature Research Collections offers Grants-in-Aid to students of American Children's Literature. Funding for this program is provided by the Saint Paul Foundation. The Hess Collection of 70,000 Dime Novels and Story Papers, and the Series Book Collection, consisting of 10,000 volumes, provide resources for the researcher.

Grants-in-Aid will be awarded to qualified scholars whose research requires the use of the collections of the Children's Literature Research Collections. Preference will be given to post-graduates, but other applications will be considered. Selected applicants will receive transportation and $\$ 25$ per diem. Hess Fellows will be selected by the Grant-in-Aid Committee in 1980 and 1981.

Applications for 1980 must be in the hands of the committee by April 1, 1980; and for 1981 by April 1, 1981. For application materials or further information, contact

Grant-in-Aid Committee

Children's Literature Research Collections 109 Walter Library

117 Pleasant Street S.E.

University of Minnesota Libraries

Minneapolis, MN 55455

(612) 373-9731

ANNOUNCEMENT V

The Midwest History of Education Society will hold its annual meeting on October 24-25, 1980, at Loyola University of Chicago. Persons interested in presenting a paper should submit two copies of the manuscript on or before May 1, 1980, to James C. Carper, Program Chairman, Department of Education, Tulane University, New Orleans, Louisiana 70118. 


\section{PAST PRESIDENTS}

Lawrence A. Cremin

Merle L. Borrowman

Lloyd P. Jorgensen

Archibald W. Anderson

Franklin Parker

Raymond E. Callahan

J.J. Chambliss

Robert L. McCaul

Ann Keppel

Paul Nash

David B. Tyack

Henry J. Perkinson

Charles Burgess

Patricia Albjerg Graham

John H. Calam

Vincent P. Lannie

Michael B. Katz

Geraldine Joncich Clifford

Clarence Karier

Jurgen Herbst

Wayne J. Urban

Carl F. Kaestle

Sol Cohen

Marvin Lazerson

Douglas Sloan
Teachers College, Columbia University

1959-60

University of Wisconsin (now the Univ

1960-61

of California, Berkeley)

University of Missouri

$1961-62$

University of Illinois (deceased)

1962-63

1963-64

1964-65

1965-66

1966-67

1967-68

1969-69

1969-70

1970-71

$1971-72$

1972-73

1973-74

$1974-75$

$1975-76$

University of Toronto (now Univ.

of Pennsylvania)

University of California, Berkeley

1977

University of Illinois

1978

1979

1980

1981

1982

1983

University of British Columbia

1984 